\title{
Toleration, Reasonableness, and Power
}

\author{
Thomas M. Besch and Jung-Sook Lee
}

\section{Contents}

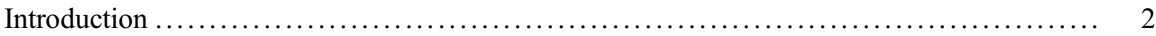

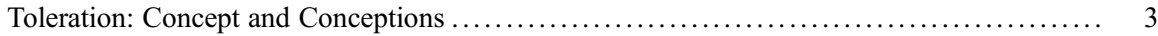

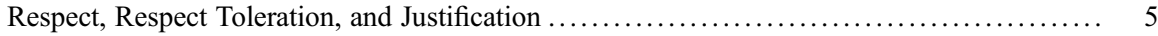

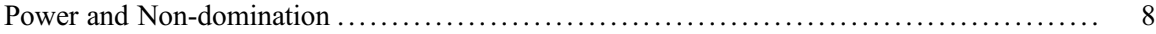

True Toleration and Non-domination? ...................................... 10

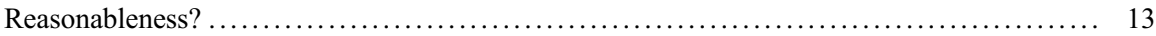

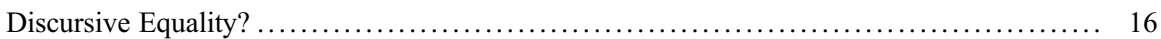

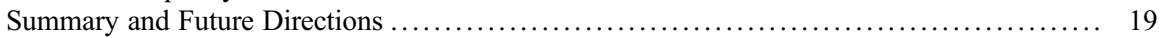

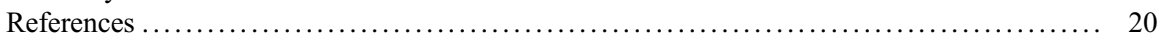

\section{Abstract}

This chapter explores Rainer Forst's justification-centric view of non-domination toleration. This view places an idea of equal respect and a corresponding requirement of reciprocal and general justification at the core of non-domination toleration. After reconstructing this view, this chapter addresses two issues. First, even if this idea of equal respect requires the limits of non-domination toleration to be drawn in a manner that is equally justifiable to all affected people, equal justifiability should not be understood in terms of Forst's requirement of reciprocal and general acceptability. Second, for the equal justifiability of relevant constraints to ensure non-domination outcomes, discursive equality must be understood in substantive, purchase-sensitive terms. This means that a justification-centric view of non-domination toleration stands or falls with the participation value of

T. M. Besch (ه)

School of Philosophy, Wuhan University, Wuhan, Hubei, China

Department of Philosophy, The University of Sydney, Sydney, NSW, Australia

e-mail: thomas.besch@whu.edu.cn; thomas.besch@sydney.edu.au

J.-S. Lee $(\bowtie)$

School of Social Sciences, UNSW Sydney, Sydney, NSW, Australia

e-mail: js.lee@unsw.edu.au 
what it regards as the standards of justification. This places reasonably contested matters of value at the heart of such views.

\section{Keywords}

Respect · Toleration · Justification · Non-domination · Discursive equality · Reasonableness $\cdot$ Discursive influence

\section{Introduction}

Can a practice of toleration impose constraints without instantiating domination? This chapter explores Rainer Forst's seminal justification-centric view of non-domination toleration (2003a, b; Forst 2017a). In a nutshell, this view finds a form of equal respect and a corresponding requirement of reciprocal and general justification at the core of non-domination toleration. For Forst, practices of toleration can instantiate non-domination toleration only if they respect all affected people as moral-political equals. To this end, he claims, these practices must only impose constraints that are justifiable to all affected people by reasons that they can equally accept - which aims to capture a "Kantian republican" sense of non-domination (Forst 2013). On this basis, Forst insists that practices of toleration should draw the limits of toleration in terms of the requirement of reciprocal and general justification.

While this view, or its underlying commitment to a demanding form of equal respect, has merits, it gives rise to two concerns. First, even if non-domination toleration is possible only where people are suitably respected as equals and this calls for the equal justifiability of relevant constraints, there are reasons not to construe the kind of justification that is called for here in terms of a Forst-type reciprocal and general justification. Given the purposes of non-domination toleration, then, it is an open question what constitutes equal justifiability.

Second, that salient constraints are justifiable in practices of justification that accord people a formally equal justificatory say does not secure non-domination outcomes unless this say allows each person to exercise a suitable level of discursive influence in justification, or on its outcomes - that is, unless this say has suitable "discursive purchase" (Besch 2019a, p. 471f). This means that the kind of discursive equality at the core of a justification-centric conception of non-domination toleration must be understood in substantive, "purchase-sensitive" terms (Besch 2019a, p. 475f). This places important, yet reasonably contestable matters of value at the heart of such a conception. And it asks us to focus on the "participation value" (Besch 2019a, p. 468) of standards of justification, and to engage the question of how the good of discursive influence can permissibly or justly be allocated across diverse constituencies.

Below, these two issues are addressed against the background of a reconstruction of Forst's view. Section "Toleration: Concept and Conceptions" considers salient aspects of the concept and some conceptions of toleration. As the focus of this chapter is on respect toleration, section "Respect, Respect Toleration, and 
Justification" elaborates on respect, respect toleration, and the idea of justification that Forst intertwines with these things. Section "Power and Non-domination" attends to the notions of power and non-domination. To complete the reconstructive part of the discussion, section "True Toleration and Non-domination?" puts these things together and specifies the contours of Forst's view of non-domination toleration. Section "Reasonableness?" then engages the idea of the reasonable that does important work in Forst's view of reciprocal and general justification. Once the question arises what "reasonable" means in this context, shortcomings of the view at hand emerge. Section "Discursive Equality?" addresses the idea of discursive equality that underpins Forst's thinking about justification and non-domination toleration. It emerges that discursive equality is compatible with problematic forms of domination unless discursive equality is understood in suitably substantive, purchase-sensitive terms. This points toward matters of value that bear on how standards of acceptability-based justification are defined, or their participation value is calibrated-matters that are more fundamental than justifications by these standards. Section "Summary and Future Directions" concludes.

\section{Toleration: Concept and Conceptions}

To provide some needed background, this section addresses the concept and conceptions of toleration; it will do so following Forst's account (Forst 2003a, b). The section begins with a note on a salient supposition of toleration.

While all toleration involves noninterference with an object of toleration, or what is being tolerated, social toleration - that is, interpersonal or intergroup relationships of toleration - supposes in tolerators some power to interfere with toleratees and assumes in toleratees a corresponding vulnerability. Betty's noninterference with Paul's drinking instantiates toleration only if she can interfere with it and hence only if Paul is vulnerable to that interference. Toleration thus supposes patterns of power. These need not be asymmetrical: for example, where toleration is mutual, it may not be. And the vehicles through which toleration is enacted need not take the form of individual acts or omissions. Vehicles of toleration can vary widely - for example, they can involve collective actions or omissions, policies and practices, norms and institutions, legislation, incentive schemes, "justification narratives" (Forst 2017a, pp. 55-74), and so forth.

Given such patterns of power, all toleration involves an "objection" component and an "acceptance" component (Forst 2017a, p. 78; 2003a, b; King 1998; McKinnon 2006). The tolerator must take it not only that there is something about the object of toleration that is objectionable or rejectable, but also that there is something about that object that is acceptable, merits approval, or is respectable. That toleration requires objection and acceptance has led some theorists to question whether toleration is coherent, viable, or desirable (Fletcher 1996; Mendus 1988; Newey 2013; Scanlon 2003; Williams 1996). In this chapter, it is assumed that toleration can be coherent and desirable. 
Next, in toleration the acceptance component "trumps" the objection component: there must be "positive reasons which trump the negative ones in the relevant context," so that the object of toleration is "considered to be wrong, but not intolerably wrong" (Forst 2003b, p. 72). For example, Betty might disapprove of the health effects of Paul's drinking, but since she also sees it as an expression of his autonomy that she has overriding reasons to respect, she does not interfere with it. The tolerator's acceptance reasons, however, may or may not be reasons that the toleratee can accept as such acceptance reasons.

Not least, all toleration is normatively bounded - a matter that will be relevant later. As Forst highlights, a practice of toleration involves two boundaries, or normative lines. One line separates things that are accepted from things that are rejected but tolerated: this line indicates where acceptance ends and toleration begins (Forst 2003b, p. 72). Another line separates these things from things that are rejected as intolerable: this line marks the outer boundary of toleration, and it is often referred to as the limit of toleration. Forst also refers to this latter line as the "rejection" component in toleration (Forst 2017a, p. 78).

It is not always apparent where practices of toleration actually draw these lines, or on what grounds they do so. And, normatively, it is often contested where these lines should be drawn and on what grounds this may be done. Particularly relevant here is the line that marks the outer boundary, or the limit of toleration. That toleration has limits is sometimes taken to call into question whether any practice of toleration can truly be tolerant - rather than merely imposing on people some conception of what is intolerable that is dogmatic, arbitrary, parochial, or oppressive. The idea that there cannot be true toleration is sometimes referred to as a "paradox" of toleration - a problem that raises deep challenges for a normative view of toleration (Besch 2010; Forst 2003a, b; Newey 2013; Rossi 2013). This issue will be revisited later.

Next, at least four conceptions of toleration can be distinguished: permission, coexistence, respect, and esteem toleration. As only respect toleration matters here, the other three are only briefly mentioned. In permission toleration, tolerators grant toleration, or relevant permissions, from a position of (assumed or actual) superiority in order to advance their own ends. For example, "an authority permits one or several minorities to live in accordance with their beliefs ... provided that they do not challenge the supremacy of this authority" (Forst 2017a, p. 78). Coexistence toleration is symmetrical and instrumental: the parties instrumentally tolerate one another as a modus vivendi (Forst 2003b, p. 74). For example, two hostile religious groups agree to no longer interfere with one another in order to avert their own destruction. Esteem toleration is symmetrical, too, but it expresses a form of "mutual recognition," albeit one that reflects a "fuller, more demanding" form of recognition than the one expressed in respect-toleration (see below) (Forst 2003b, p. 75). Esteem toleration is based on "ethical esteem" of tolerated beliefs as "ethically attractive and held for good reasons," although this esteem is "reserved," insofar as tolerators regard these beliefs as less attractive than their own (ibid). For example, Muslim Betty and Christian Paul positively value each other's religions as forms of monotheism, although each believes their own faith to be closer to the truth.

What matters here is what Forst calls the respect conception of toleration. Respect toleration is symmetrical and moral, rather than instrumental: it expresses a form of 
moral respect (Darwall 1977). In respect toleration, the parties may "hold incompatible ethical beliefs about the good and right way of life," but they "respect each other as moral-political equals in the sense that their common framework of social life should ... be guided by norms that all parties can equally accept" (Forst 2003b, p. 74). Elsewhere, Forst adds:

\begin{abstract}
Although [the parties] differ sharply in their respective notions of the good and of salvation, they accord each other a status as equals which states that generally valid norms must rest on reasons that all those affected can accept equally and do not favour one side ... The "authority" to "bestow" liberties... resides ... in a process of general legitimation that provides for a special level of justification in questions of principle. (Forst 2017a, p. 79)
\end{abstract}

This ties respect toleration to equal acceptability justification. When Betty respecttolerates Paul, she respects him as a moral-political equal, or as an equal authority of justice and justification - and hence as someone who has, or should be accorded, a discursive status such that moral or political things (such as norms, institutions, and social structure) that affect Paul must be justifiable to Paul on the basis of reasons that are equally acceptable by him. Hence, to respect-tolerate people in this sense commits to the view that where they are relevantly affected, they are owed justifications by reasons that are equally acceptable by them.

Not least, the above depicts respect toleration as interagentive in the narrow sense of a relationship between individual agents, but respect toleration can also be an intergroup phenomenon, or a group-level response of one social group to another such group (Galeotti 2002). In this chapter, it is assumed that toleration is interagentive in a wide sense: it can instantiate as a relationship between individual or collective agents.

\title{
Respect, Respect Toleration, and Justification
}

This brings us to the idea of equal respect that Forst-type respect toleration implicates. The idea of robust discursive equality that this kind of toleration entails will be discussed later, given the idea of equal respect that it builds on. It hence is useful to now elaborate on this idea and to register, as well, that respect toleration can be premised on different ideas of respect.

To start with, Forst's rendering of respect toleration is not doctrinally innocuous. It conceptualizes respect toleration in a manner that ties it to a particular view of respect and a particular kind of justification. And of course it is contested what kind of reason giving, if any, proper respect for other people calls for (Carter and Ferretti 2013; Rossi 2013; Besch 2010, 2018, 2019b). Even assuming that proper respect for other people is a kind of recognition respect that responds to morally important features of them - to mention just a few prominent candidates, these features might be their capacity for agency, autonomy, personhood, or their being free and equal, reasonable people, and so on (Darwall 1977; Raz 1986; Macedo 1991; Postema 1995; Kymlicka 1996; Rawls 2005; Larmore 2015) - it is open how we should 
respond to these features. This point can be elaborated by contrasting two ideas of equal respect that would yield different views of respect toleration.

First, consider the familiar view that equal respect requires treating others as equal recipients of justice. On such a view, conduct or social structure that affects people can respect them properly only insofar as it is just in a substantive sense - that is, it must accord with the content of justice, or the rights, liberties, or opportunities that just social structure allocates to people. Equal respect in this sense is a conception-dependent constraint the content of which is given by, or is defined in terms of, a (putatively) authoritative, reasonable, or justifiable conception of justice. Consequently, respect toleration in this sense commits to noninterference with other people - or their conceptions of what is good, right or true, their choices, practices, or forms of life, and so forth - only insofar as the content of justice calls for it, as defined accordingly.

One upshot: prior to knowing what justice calls for, substantively speaking, equal respect in the conception-dependent sense leaves open whether actions, practices, or institutions that relevantly affect people must be justifiable to them on the basis of reasons that they can equally accept - rather than, for example, reasons that they could or would accept at some high level of idealization (e.g., when fully rational or perfectly responsible epistemically), or reasons that actually apply to them whether or not they realize that this is so (Wall 2016; Steinhoff 2015; Besch 2010, 2019a, b).

A different view of equal respect typically is in play in "recognitive" conceptions of acceptability-based public justification (Besch 2019b, p. 613; see also section "Discursive Equality?", below). On such views, equal respect is not simply something the content of which is defined by a putatively authoritative conception of justice. Rather, it is (primarily) a constraint on the justifications that people are owed in relevant moral or political matters, including justifications of the standards and values of justice that (putatively) just social structure applies to them. The idea here is that a justification of moral or political things must accord each relevant person a meaningful level of discursive influence in justification, or on its outcomes, so as to respect each person not simply as a recipient, but as an equal co-author or equal authority of justification (Forst 2017a, p. 134; 2017b, p. 545). Where equal respect is construed in such justification-constraining terms, it is often conjoined with three other views (for relevant things, such as conduct, practices, or social structure, $\varphi$ ):

(i) $\varphi$, to equally respect relevant people, needs to accord with principles or values that are justifiable to them by reasons that are equally acceptable by them (the equal acceptability requirement),

(ii) While people must have a meaningful say in justification, they must have some measure of influence on what can or cannot count as justifiable to, or equally acceptable by, them (the discursive influence requirement).

Not least, (i) and (ii) often come intertwined with a constructivism requirement according to which relevant moral or political things depend for some relevant moral or political merit on their equal acceptability: 
(iii) The principles or values referred to in (i) are valid (or right, or reasonable) only if they are justifiable to all relevant people by reasons that are equally acceptable by them (the constructivism requirement).

These views mark different elements of the idea that others should be respected as equal authorities of justification in the justification-constraining sense. Equal respect, when it is construed along such lines, takes the form of discursive respect and requires that people be accorded a form of robust discursive equality (Besch 2014, 2019a; this is discussed further below).

What does this entail at the site of toleration? When premised on justificationconstraining respect, respect toleration calls for noninterference if and when interference - or principles, values, or policies, and so on, that would call for interference - cannot be justified to all affected people by reasons that, in a suitably meaningful sense, are equally acceptable by them. Plainly, this can point us in different directions than a practice of respect-toleration that builds on respect in the conceptiondependent sense. What conception-dependent respect-toleration calls for cannot be identified independently from the contents of a conception of justice. But what a putatively authoritative conception of justice prescribes might not also be justifiable by reasons that, in some suitably meaningful sense, each of the relevantly affected can equally accept.

Forst construes equal respect primarily in a justification-constraining sense. As he puts it in a passage quoted earlier, in exercising respect toleration, people "respect each other as moral-political equals in the sense that their common framework of social life should ... be guided by norms that all parties can equally accept" (emphasis added). This refers to Forst's requirement of reciprocal and general acceptability (or RGA, for short), understood as a requirement of justification. According to RGA, moral or political normative claims, to be justified, or valid, must be equally acceptable, or non-rejectable, by all affected people; at stages Forst takes this to require that justifications be based on reasons that no-one can reasonably reject (Forst 2017a, p. 28f; 2012, p. 21; 2010; 2013; Besch 2010; see also section "Reasonableness?", below). However, to respect people as moral-political equals, or as equal authorities of justification, is to respect them as people to whom justifications are owed in matters that affect them that meet RGA - and this means to respect them as equal authorities of justification (Forst 2017a, pp. 134, 6ff).

This ties equal respect to variant of the equal acceptability requirement and the constructivism requirement (see above). It also ties it to a variant of the discursive influence requirement. Forst assumes that where reason giving meets RGA, it accords affected people a qualified veto-right that (putatively) protects or helps to protect them from domination (Forst 2001, p. 168f; 2010, p. 719). Evidently, the assumption here is that people can use these veto rights to bring to bear their voice on what can or cannot count as justifiable to them. It is on the basis of this assumption that Forst attributes to reciprocal and general justifications an emancipatory or protective function and finds them at the normative core of a "basic structure of justification" that enables true non-domination (Forst 2017a, pp. 6f, 131-137; 2013, 
p. 155). Hence, justifications that meet RGA (putatively) accord people a measure of discursive influence in justification.

What matters for this chapter is only respect toleration in the second, justificationconstraining sense. While the focus is on Forst's view here, the issues to be explored later are not specific for his approach. Forst, of course, is not the only theorist who construes respect toleration in justification-constraining terms. Seminal on the point is Rawls-type political liberalism - which strongly influences Forst. As Rawls observes, "political liberalism applies the principle of toleration to philosophy itself" (Rawls 2005, p. 10). The label "toleration" here refers to a respect-based commitment to avoid reasonable disagreement in public justification - or a principle of justificatory neutrality (Larmore 2015, pp. 68-74). For Rawls and other political liberals, political power can properly respect reasonable citizens as free and equal, and hence be legitimate, only if it is publicly justifiable to them on grounds they can equally accept (Besch 2012). Yet values, conceptions, or doctrines fail to be so acceptable when reasonable citizens reasonably disagree about them. Thus, no conception of justice can provide a basis for a publicly justifiable, legitimate exercise of political power unless it avoids reasonable disagreement - a conclusion that motivates the project of a political liberalism. In short, political liberalism adopts a justification-constraining idea of equal respect - that is, a demanding form of discursive respect (Besch 2018) - and shapes in this light its view of public justification.

\section{Power and Non-domination}

Next, the relationship between toleration and power is discussed, starting with remarks on power.

As Allen (2015) observes, power can be present as power-over or domination, power-to or agentive resource, or power-with or a form of collaborative agentive empowerment. What matters here is only power-over. In clear-cut cases, power in this form is or entails a relationship of influence between individual or collective agents such that one agent $\alpha$ (in the role of power agent) imposes constraints on another agent $\beta$ (in the role of power subject). This relationship may or may not be symmetrical (e.g., $\alpha$ and $\beta$ might each occupy the role of power agent and power subject vis-à-vis each other), it may or may not be voluntary, and it may or may not be morally or otherwise objectionable. In less than clear-cut cases, an interagentive schema does not or not clearly apply. For example, in the case of "systemic" domination, a "system of social relations" rather than any particular individual or collective agent, subjects all agents to its "functional imperatives" (Azmanova 2018, p. 69). Other cases involve interagentive power, but power agents merely administer power rather than also sourcing it. For example, where government officials use the powers attached to their offices to impose constraints on people, they may act as power agents, but they do not source the power they administer - that source resides in the institutions that appoints them to their offices and that attaches to these offices the relevant powers. 
The focus of this chapter is on a particular kind of power-over, namely, domination. When $\alpha$ dominates $\beta$ (in the sense relevant here), $\alpha$ exercises power over $\beta$. If domination entails power-over, what distinguishes it from other kinds of powerover? This chapter considers a republican answer to this question. Roughly, republican views tend to conceptualize the phenomenon of domination by considering in what way (if any) agents can bring to bear their perspective or will on the constraints that apply to them. Specifically, they take domination to occur where agents cannot relevantly influence what constraints apply to them.

For instance, on Pettit's (2012) control-centric account, a government dominates citizens when they cannot make use of relevant political or social tools, such as political participation rights or opportunities for political speech, to exercise a relevant level of control over the political or legal constraints that the government applies to them. More relevant now, however, is Forst's justification-centric, "Kantian republican" view (Forst 2013). On this view, political power instantiates domination when it imposes constraints on people that are not justifiable to them "reciprocally and generally," or on grounds that all affected people can equally accept (e.g., ibid., pp. 157, 159f). How so?

Forst adopts a justification-centric version of an "arbitrary power" conception of domination (Lovett 2010, Chapter 4). For Forst, domination occurs when people are subjected to arbitrary constraints, while he construes constraints as arbitrary if and when they lack "adequate justification" (Forst 2013, p. 155) or "legitimate reason" (ibid., 157). And in moral or political contexts, non-arbitrariness calls for justifications on the basis of reasons that are equally acceptable by all affected people. The upshot: if $\beta$ is subjected to constraints, $\varphi$, this does not instantiate domination so long as $\varphi$ is justifiable by reasons that $\beta$ can equally accept. Consequently: if we do not know or have reasons to doubt whether $\varphi$ is so justifiable, then we do not know or have reasons to doubt whether $\beta$ 's subjection to $\varphi$ instantiates non-domination power-over.

In essence, this conjoins two familiar views: it grafts a view of non-domination as justifiable subjection onto an idea of equal (discursive) respect as calling for justifications on grounds that relevant people can equally accept. On this view, the good of equal (discursive) respect is the key good that stands to be secured where power over others is exercised; accordingly, justifiable subjection is conceptualized in terms that reflect a view of what it takes to properly secure that good. And so the idea becomes that non-domination power-over must impose suitably justifiable constraints, where this is interpreted as calling for equal acceptability justifications.

Before moving on, two things need to be highlighted. First, the view of nondomination in play here has a political ring, but it applies not only to political power in the narrow sense of state power. Forst's focus is on (non-)arbitrary constrains in a wide sense. He understands "arbitrariness"

in a social sense, whether it assumes the form of arbitrary rule by individuals or by part of the community (for example, a class) over others, or of the acceptance of social contingencies that lead to asymmetrical positions or relations of domination and are defended and accepted as an unalterable fate, even though they are nothing of the sort. Arbitrary rule is the rule of some people over others without legitimate reason, that is, domination, and where struggles 
are conducted against injustice they are first and foremost directed against forms of domination of this kind. (Forst 2013, p. 157)

Arbitrary constraints need not be political to constitute domination. Thus, in the domain of the political and elsewhere, non-domination power-over requires constraints that people are subjected to be justifiable to them on equally acceptable grounds - only in this case can the imposition on them of these constraints suitably respect them as moral-political equals.

Second, also a justification-centric view of (non-)domination must place importance on something in the way of control over the constraints that apply to agents. The justifiability of relevant constraints can plausibly distinguish domination powerover from non-domination power-over only insofar as justification is understood in terms that allocate power subjects a relevant measure of influence on what constraints apply, or may apply, to them. Thus, much here depends on the level of discursive influence that agents can exercise in justification. And this puts center stage what we called earlier the discursive influence requirement. Forst is not unaware of this. If the constraints that $\alpha$ imposes on $\beta$ are not equally acceptable by $\beta$, Forst, it seems, would insist that $\alpha$ should see this as a reason not to impose these constraints on $\beta$. After all, he takes it that people should be respected as moralpolitical equals, and he often puts this point also by saying that this involves according them a (qualified) veto right in matters that affect them (Forst 2001, p. 168f; 2010, p. 719).

The point: a justification-centric view must give importance to control or influence over constraints, although it might foreground reason giving - or "institutionalized justification procedures" (Forst 2013, p. 159) - as a method through which control or influence is exercised.

\section{True Toleration and Non-domination?}

This section addresses the theme of non-domination toleration. It has often been argued that toleration can involve domination (Galeotti 2002; Forst 2003a, b; Honohan 2013). Practices of toleration distinguish between things that are counted as tolerable and things that are seen as intolerable, (strictly) impermissible, or as proper objects of reproach, punishment, prosecution, or other negative social sanctions. And when views of the limits of toleration are legally, politically, or otherwise imposed on agents, they take the form of constraints on them, or their agency. Thus: at least when practices of toleration impose their views of these limits in the form of such constraints, they involve power-over. If this is so, what does it take for such practices to instantiate non-domination toleration?

To start with, when do questions of toleration arise? According to Forst,

the context in which the question of toleration between citizens arises is a context of justice: what is at issue here is the just - that is, mutually justifiable - legal and political structure for a pluralistic community of citizens with different ethical beliefs. Claims for toleration are 
raised as claims for justice, and intolerance is a form of injustice, favouring one ethical community over others without legitimate grounds. (Forst 2003b, p. 76)

This understands "the question of toleration" in terms of the question of when exercises of political power - specifically, legal or political constraints - are just or justifiable. For Forst, then, toleration and political non-domination are different sides of the same coin. Either way, the key normative issue is whether salient constraints properly respect people as moral-political equals. And either way, constraints can do so only if they are justifiable by reasons that are equally acceptable by relevant people.

To elaborate, consider first real or true toleration - as opposed to practices of toleration that distinguish between the tolerable and the intolerable in terms that are intolerant. This relates to one of the "paradoxes" of toleration, that is, the "paradox of drawing the limits" (Forst 2003a, p. 38ff; 2003b, p. 70ff). Says Forst:

\footnotetext{
All toleration necessarily implies intolerance toward those who are seen as intolerable ... The concept of tolerance makes no sense without certain limits, though as soon as these are substantively defined, tolerance seems to turn into nothing but intolerance. There is thus no "true" tolerance. To resolve this paradox a conception of toleration must show how far its limits can be drawn in a mutually justifiable and non-arbitrary way. (Forst 2003b, p. 72)
}

However, the paradox can be overcome if the limits of toleration are drawn in terms that suitably respect all affected people as moral-political equals, and that cannot be rejected reasonably. To this end, this line must be drawn on the basis of RGA itself, the requirement of reciprocal and general acceptability (Forst 2003b, pp. 76-78). (This notion of "drawing" or "defining" the limits of toleration refers not merely to the intellectual activity of defining those limits, but also to the social, legal or political imposition or enforcement of views of these limits.)

Two main lines of thought are in play here. First, of course, Forst puts to work the idea that people should be respected as moral-political equals - or as equal authorities of justice or justification, or, as he also says, as agents who are equally "worthy of being given adequate, justifying reasons in matters that affect them," or who have an equal "right to justification" (Forst 2003a, pp. 76f, 81). As such, agents are owed reciprocal and general justifications in matters that affect them. Thus, social structure that imposes on them a view of the limits of toleration must be justifiable to them on grounds that they can equally accept, while respect toleration - where "respect" is understood as discursive respect, in a justification-constraining sense - is a "superior" kind of toleration (Forst 2003a, p. 76).

Second, since the limits of toleration must be drawn in terms that do not depend for their justification on grounds that can reasonably be rejected, they should be drawn on the basis of RGA itself. That is, to draw these limits in a way that suitably respects people, they must be drawn in terms that are justifiable on grounds that are equally acceptable by all affected people. For Forst, this calls for a justification on grounds that no affected person can reject reasonably. And here, he looks to RGA: for Forst, RGA cannot be rejected reasonably. Thus, he offers RGA as a standard by which to draw the limits of toleration. Accordingly, 
[c]itizens are tolerant if they accept the boundary set by the criteria of reciprocity and generality as both delineating the justifiability of mutually binding norms and the limits of toleration. Tolerant citizens are 'reasonable' in accepting that (...) an ethical objection does not amount to a legitimate moral rejection; and they also see that they have a moral duty to tolerate all those ethical beliefs and practices that they disagree with but that do not violate the threshold of reciprocity and generality (trying to force their views on others). Such a violation of the basic right to justification is a form of intolerance that cannot be tolerated. (Forst 2003b, p. 78; Forst's emphasis)

Persons are tolerant to the extent that ... they tolerate all other views within the bounds of reciprocity and generality. (Ibid., p.78)

Being tolerant ... means seeking reasonable justification, accepting reasonable disagreement within the limits of reciprocity and generality, and being aware of the different contexts of justification that persons are part of. (Ibid., p. 81)

This suggests the following view (for a candidate object of toleration, $\varphi$ ):

1. Practices of toleration must respect all affected agents as moral-political equals, or as equal authorities of justification.

2. To this end, the (legal, political) limits of toleration must be drawn in terms that are reciprocally and generally justifiable.

3. Thus, the (legal, political) limits of toleration must be drawn in terms that do not depend for their justification on grounds that can reasonably be rejected.

4. Practices of toleration should (legally, politically) limit toleration on the basis of RGA itself.

5. Hence: if (legally, politically) interfering with $\varphi$ would not be reciprocally and generally justifiable, $\varphi$ is tolerable; but if (legally, politically) interfering with $\varphi$ is so justifiable, then $\varphi$ is intolerable.

This appears to be the core of Forst's normative conception of non-domination toleration. Claims (2) to (5) draw out what practices of toleration must be like to properly instantiate (1), while the notion of "reciprocal and general justification" in (2) refers to justifications on the basis of reasons that are equally acceptable by all affected people.

Forst believes that his view overcomes the "paradox of drawing the limits." When the line between the tolerable and the intolerable is drawn in terms of RGA, it is drawn in a manner that extends equal respect to all affected people:

By drawing the 'limits of toleration' with the help of the criteria of reciprocity and generality, we draw them ... in the widest possible way given the existence of a large diversity of world-views, without sacrificing one for the sake of the unjustifiable claims of another. Thus there is not arbitrary substantive content that defines the tolerable; this content is open to dispute and argument, and protection is given to those voices in danger of being marginalized. Those who violate the basic norm of mutual respect implied by that cannot claim to be the victims of intolerance. (Ibid., p. 82) 
Hence, if the limits of toleration are drawn in suitably justifiable terms, practices of toleration do not dominate: the constraints that they impose will respect each affected person as moral-political equals.

\section{Reasonableness?}

This conception of non-domination toleration has limits. The role that it accords to an idea of equal (discursive) respect has much moral appeal. But there are reasons to doubt the coherence of this conception. To explain why, this section begins with comments on the idea of the reasonable at work in Forst's conception of nondomination toleration. After that, section "Discursive Equality?" will address the idea of equal respect on which this conception builds, or the kind of discursive equality it entails.

Recall: Forst claims that practices of toleration must respect people as moralpolitical equals, but can do so only if the standards by which these practices draw the limits of toleration - that is, the standards that serve as their criterion of toleration cannot reasonably be rejected. On this basis, Forst offers RGA as a criterion of toleration. But is RGA reasonably non-rejectable? Consider the content Forst builds into his idea of reasonableness:

The epistemological element of being reasonable consists in an insight into the finitude of both theoretical and practical reason in finding 'final' answers to the question of the good that all can agree on ... [and] in an insight into the possibilities of reason, that is, the capacity of reaching mutually justifiable normative answers. [This commits to] the task of finding and defending justifiable reasons, because this is what reasonable and finite persons ... owe to each other. (...) [T] he normative element of being reasonable implies this form of respect for others as reasonable and worthy of being given adequate reasons; that is respect for their basic right to justification. Both elements in combination (...) are the basis for the acceptance and the recognition of the threshold of reciprocity and generality. They provide the essential reasons for being tolerant. Being tolerant thus means seeking reasonable agreement within the limits of reciprocity and generality, and being aware of the different contexts of justification that persons are part of. (Forst 2003b, p. 80f)

This effectively defines into reasonableness (i) a commitment to respect people as moral-political equals in Forst's justification-constraining sense, and (ii) a commitment to the view that people are owed reciprocal and general justifications in moral or political matters that affect them, that is, justifications that meet RGA. Although reasonableness so construed is philosophically interesting and these commitments are, to some extent, morally attractive, various concerns arise.

First, these commitments can be rejected reasonably - unless we first define reasonableness in philosophically partisan terms. As Moore (1996) observes, as far as the meaning of the word "reasonable" in ordinary discourse is concerned, "reasonable" people are committed to reason-giving, or justification, and they take it that other people are worthy of reason-giving and moral consideration. But a commitment to reason-giving, or justification, is not a commitment to Forst-type 
reciprocal and general justification. And a commitment to the view that people merit moral consideration is not a commitment to accord them equal respect, or to respect them as moral-political equals in a justification-constraining sense. The point: people can be "reasonable" in an ordinary discourse sense of the word even if they deny, doubt, or do not act in accordance with, the view that people should be respected as a moral-political equal in a justification-constraining sense, or the view that other people are owed reciprocal and general justifications, or the view that the goodness of good, justifying reasons depends on their equal acceptability by all affected people, and so forth.

Second, Forst has reasons not to define the commitments referred to in (i) and (ii), above, into his idea of reasonableness. On the one hand, this must render the claim that RGA is reasonably non-rejectable trivial, if not viciously circular. It is unsurprising that reasonable people in Forst's sense - say, reasonable-F people - cannot coherently reject RGA. After all, reasonableness- $F$ is construed as involving a commitment to reciprocal and general justification. Hence, the claim that RGA, or adopting RGA as a criterion of toleration, is reasonably-F non-rejectable (or equally acceptable, or non-rejectable, by reasonable-F people) cannot carry justificatory weight: the circle is too narrow.

On the other hand, other things being equal Forst cannot index a criterion of toleration to the perspective of reasonable-F people without undermining his own, inclusive intentions. On his view, a practice of non-domination toleration must respect all affected people as moral-political equals, while this calls for justifications on the basis of reasons that all affected people can equally accept. What matters for non-domination toleration hence cannot merely be a criterion of toleration that is equally acceptable only by reasonable-F people: this would be objectionably exclusionary also by Forst's own lights.

A third issue relates to two potentially competing requirements at work in Forst view. Recall: on this view, a practice of non-domination toleration must respect people as moral-political equals. To this end, he claims, it must draw the limits of toleration in terms that are justifiable to all affected people by reasons they can equally accept. But he insists that these limits must be drawn in reasonably nonrejectable terms (i.e., reasonably-F non-rejectable terms). Thus, he claims:

(i) A criterion of toleration must be justifiable by reasons that are equally acceptable by all affected people.

(ii) A criterion of toleration must be reasonably non-rejectable.

However, what is the relationship between (i) and (ii)? (i) and (ii) can point in different directions: that $\varphi$ cannot be rejected "reasonably" (on some definition of the term or other) does not mean that $\varphi$ is justifiable by reasons all affected people can equally accept - and vice versa. And if (i) and (ii) can point in different directions, what condition must a practice of toleration meet to suitably respect people as moralpolitical equals? 
Things are complicated further by the obscurity of what (putative) reasons must be like to count toward justification. According to RGA, reasons can justify salient claims only if they are reciprocally and generally acceptable, or non-rejectable. This has so far been interpreted in terms of the requirement that suitably justifying reasons must be equally acceptable (reciprocity) by all affected people (generality). But this simplifies. Forst sometimes suggests that a (candidate) reason to $\varphi$ is a reciprocally and generally acceptable (or non-rejectable) reason to $\varphi$ only if no relevant person can "reasonably" reject $\varphi$ 's (alleged) status as such a reason - that is, only if $\varphi$ 's (alleged) role as such a reason is reasonably non-rejectable (Forst 2012, p. 21). Roughly, this understand (i), above, in terms of (ii): if we want to know whether a candidate criterion of toleration is justifiable by reasons that are equally acceptable by all affected people, then we need to consider whether it is reasonably nonrejectable.

Premising reciprocity and generality on some reasonableness constraint addresses an important need. All conceptions or practices of acceptability-based justification must somehow qualify the kind of acceptability or non-rejectability that they regard as contributing to justification: for equal acceptability to justify, it must also be respectable, or authoritative-for example, it must be rational, coherent, epistemically responsible, or, as it were, reasonable. Acceptability-based justification hence is normatively indexed to the authoritativeness constraints that it (openly or tacitly) adopts. However, such constraints often are in their own right contested. This is so especially where these constraints are nontrivial - that is, where they impose requirements that not all relevant people always meet anyway. Thus, premising reciprocity and generality on an idea of reasonableness inevitably raises deeper questions of justification: much here hinges on the content of the idea of reasonableness that comes in here and whatever reasons there are to premise reciprocity and generality on it.

It emerged earlier that Forst's notion of the reasonable is potentially problematic, given its content. Forst's explicit comments on the meaning of the notion of reasonable non-rejectability appear to compound matters. He stresses that while he takes the phrase "reasonably non-rejectable" from Scanlon, he "interpret[s]" it in terms of his criteria of reciprocity and generality in order to "more precisely define the meaning of "reasonable" than Scanlon did" (Forst 2012, p. 272; emphasis added). This is in play when Forst more recently writes:

Adapting Thomas Scanlon's formulation ("not reasonable to reject"), I believe that moral justification requires that norms must rest on reasons that are not reciprocally and generally rejectable. (Forst 2017a, p. 28f)

But then Forst seems to hold that a reason, $\varphi$, is a "reciprocally and generally" acceptable (or non-rejectable) reason only if $\varphi$, or its role as a reason, is "reasonably" non-rejectable, while $\varphi$, or its role as a reason, can qualify as "reasonably" nonrejectable only if it is "reciprocally and generally acceptable" (or non-rejectable). As this seems to be circular, it raises the question how anything could non-arbitrarily, without mere stipulation, be claimed to be reciprocally and generally justifiable (see 
also Besch 2020). This threatens to collapse the view of justification onto which Forst grafts his view of non-domination toleration.

The point: even if practices of toleration instantiate non-domination toleration only if they extend equal (discursive) respect to all affected people, and even if such practices must only impose constraints that are equally justifiable to each affected person, there are reasons not to understand the kind of justification called for here in terms of a Forst-type conception of reciprocal and general justifiability. It remains open what constitutes the kind of equal justifiability that is needed for the purposes of non-domination toleration.

\section{Discursive Equality?}

This section focuses on the idea of discursive equality that underpins Forst's conception of non-domination toleration. As discussed earlier, this conception places a demanding form of equal respect at the heart of non-domination toleration. For Forst, practices of toleration must respect people as moral-political equals, or as equal authorities of justification, but can do so only if the constraints that they impose on people are justifiable to them by reasons that they can equally accept. Thus, on this conception, each affected person has or should have an equal justificatory say in relation to such constraints - a say, moreover, that allows people to exercise some relevant level of discursive influence on what constraints apply or may apply to them. In other words, equal respect here requires that relevant people be accorded a robust form of discursive equality (Besch 2019a).

The idea of discursive equality marks a familiar theme. Variants of the idea are typically in play in recognitive conceptions of moral or political justification (Besch 2019 b, p. 613). On such views, justification practice must suitably cohere with or express proper respect for or recognition of actual people. Specifically, such views take it that justification can properly respect people as equals only where it accords them a meaningful equal justificatory say. Thus, such views tend to construe the standards of justification in terms that idealize less, rather than more, so as to ensure that people can exercise their say in justification in a manner that relevantly tracks their actual voice and perspective (Besch 2019b, pp. 608-614). Accordingly, such views foreground the participation value (Besch 2019a, p. 468) of justification as a key dimension in which to calibrate the normativity of the standards of justification. Salient examples include the views of public justification advanced by political liberals like Rawls (2005), Macedo (1991), Larmore (2015), or Forst's conception of reciprocal and general justification.

Despite its prominence and moral appeal, the idea of discursive equality is not without problems. One feature of this elusive idea is particularly relevant here: discursive equality is compatible with forms of domination unless it is construed in suitably substantive terms. But it is not obvious what these terms should be, while any substantive view of discursive equality is likely to attract reasonable disagreement. This further complicates the idea of a justification-centric, republican form of non-domination toleration. 
Consider first the difference between formal and substantive discursive equality (Besch 2019a, p. 473f). Recall that all acceptability-based justification must qualify the kind of acceptability that it regards as justifying: for equal acceptability to justify, it must also be authoritative. Now, the authoritativeness constraints that justification practice adopts can accord people more or less discursive influence in justification, given their actual voice or perspective, or their actual deliberative resources (as opposed to the voice or perspective or deliberative resources that they would bring to bear in justification if they perfectly satisfied the relevant authoritativeness constraints) (Besch 2019a, p. 4271f; Besch 2019b, pp. 606-611). For example, if rejections must be ideally rational or fully reasonable (on some definition of what this takes or other) in order to negatively contribute to $\varphi$ 's justification status, actual people can have very little discursive influence in justification. What Paul is actually committed to reject or cannot actually accept coherently can be very different from what he could or would reject if he was ideally rational or fully reasonable. And if this difference is large enough, then Paul's actual voice and perspective can be deprived of any real discursive influence in justification or on its outcomes.

One upshot is this: a justificatory say - more generally, discursive standing - can be (or fail to be) equal in more than one respect. It can be (or fail to be) equal in a formal sense as a matter of the consistent application of relevant standards and constraints to people, and in a substantive sense as a matter of the discursive influence that an application of these things to people allows them to exercise in justification, or on its outcomes. Roughly, a justification practice, JP, accords $\alpha$ and $\beta$ formally equal discursive standing when JP accords $\alpha$ and $\beta$ a justificatory say and applies to each the same standards and constraints, such as the same authoritativeness constraints. But JP accords $\alpha$ and $\beta$ substantively equal discursive standing only if their discursive standing allows them to exercise the same level of discursive influence in justification, or on its outcomes - that is, only if their discursive standing has the same discursive purchase (Besch 2019a, p. 417f; 2019b, p. 606f; 2014, p. 216ff).

The following example helps to clarify the distinction at work here, and it substantiates that formal discursive equality is compatible with domination. Let JP1 be a justification practice that adopts a negative variant of an equal acceptability requirement (Besch 2019a, p. 474f):

JP1 $\varphi$ is valid if and only if no affected person can authoritatively reject (i.e., in JP1, all affected people have a justificatory say vis-à-vis $\varphi$, and JP1 applies the same standards, including its authoritativeness constraint, $\psi$, throughout).

JP1's constituency includes Dominant Group and Marginal Group. Over time, Dominant Group has used its social influence and "occlusion" power (Jenkins and Lukes 2017), to define $\psi$ in terms of values that it accepts and Marginal Group rejects: JP1 recognizes discursive input as authoritative, or as positively or negatively contributing to justification, only insofar as this input is compatible with the values of Dominant Group.

JP1 satisfies formal discursive equality: in JP1, it is true of each agent that $\varphi$ can count as justified or valid only if $\varphi$ cannot authoritatively be rejected by that agent. 
But JP1 does not also instantiate substantive discursive equality; and the way in which it fails to do this is problematic. Members of Marginal Group do not have equal influence in justification, or on its outcomes; they do not have (substantively) "equal opportunity for political influence" (Cohen 2006, p. 242), or (substantively) equal opportunity "to participate in the process of public deliberation" (Peter 2009, p. 67), or do not enjoy equal substantive inclusion (Dieleman 2015, p. 803). JP1 filters, brackets, or hypotheticalizes their voice or perspective in a way in which it does not filter, bracket, or hypotheticalize the voice or perspective of members of Dominant Group. And so JP1's authoritativeness constraint can make it impossible for members of Marginal Group to effectively contest or reject the values of Dominant Group. Thus, JP1 entrenches the dominance of Dominant Group, and it turns justification practice itself into a vehicle of domination, or forms of it, such as "hermeneutic" domination (Catala 2015).

Consequently, in order to attain non-domination outcomes, it is not enough to ensure that relevant constraints are justifiable in justification practices that accord people a formally equal justificatory say. It must also be the case that their justificatory say is not problematically or impermissibly unequal, or too low, in discursive influence. This suggests that the kind of discursive equality that is called for here is purchase-sensitive (Besch 2019a, p. 475f): if we assume that discursive equality requires a formally equal justificatory say, we have reasons to assume, as well, that discursive equality depends on the level of discursive influence that the having of such a say allows each agent to exercise in justification, or on its outcomes, given their actual voice and perspective. But what level of discursive influence is the right level?

This is not the place to delve into this vexing question, or to engage competing views on the matter (e.g., see Forst 2013, p. 165; Besch 2019b, pp. 618-621; Besch 2019a, pp. 476-485). Merely two things can be highlighted. First, there are reasons to construe the kind of discursive equality that underpins Forst's conception of nondomination as purchase-sensitive. To attain non-domination outcomes, an equal justificatory say must allow people to exercise a suitable level of discursive influence in justification. How much or how little influence this calls for is an open question and one that appears to involve deeper matters of value. This is so if it is true that a high level of discursive influence, or "high-purchase discursive standing," is an "inclusive enabler good," or "a good that we value, or have reasons to value, and that helps to protect and support the pursuit of a wide (but not unlimited) range of conceptions of what is good, right, or true" (Besch 2019a, p. 427f). The matter at hand, then, appears to raise questions about the permissibility, justness, or the desirability of ways to allocate a potentially highly important discursive good.

Second, the matter at hand concerns the conditions under which a standard like RGA can confer authority. Consider:

(i) In terms of what idea of the reasonable should we define the authoritativeness constraints of reciprocal and general justification (e.g., for the purposes of a justification of the constraints that practices of toleration impose on people)? 
That no relevant person can "reasonably" reject $\varphi$ cannot justify $\varphi$ if an objectionable idea of the reasonable is in play. And an idea of the reasonable is objectionable if it leaves people with too little discursive influence or entails impermissible interpersonal differences in discursive influence. If so, then questions like the following mark a theme that is constitutive for the authority, or normativity, of reciprocal and general justification:

(ii) How much discursive influence in justification, or on its outcomes, should the justificatory say of relevant people allow them to exercise (in their own right, and vis-à-vis others)?

If we do not know how (ii) must be answered, then we do not know how we may interpret, or calibrate, the normative content of standards like RGA. But if this is not known, then we do not know whether the fact that salient constraints are justifiable by such a standard can really justify them, constitute their authority, or secure nondomination outcomes.

It is an open question how the participation value of standards like RGA must be calibrated in order to ensure non-domination outcomes. And this question invites much reasonable disagreement. More than one pro tanto reasonable view is available about the conditions that justification standards must meet to permissibly allocate the good of discursive influence across diverse constituencies (e.g., consider the views sampled in Besch 2019a, pp. 476-485).

Thus, the theme of discursive equality marks a gateway to deeper questions of value. It puts the participation value of justification at the center of a justificationcentric conception of non-domination toleration, and it asks us to (re)consider the idea of non-domination toleration in this light. Even if a practice of toleration only imposes constraints that are justifiable by reasons that all relevant people can equally accept authoritatively, or cannot authoritatively reject, non-domination outcomes are not guaranteed. For the question remains whether the authoritativeness constrains that are in play suitably allocate discursive influence. And if this matter invites reasonable disagreement, there will be reasonable disagreement at the heart of a duly accountable conception of non-domination toleration.

\section{Summary and Future Directions}

This chapter focused on the idea of non-domination toleration, or its normative form, through the lens of a discussion of Forst's republican conception of non-domination toleration. Non-domination toleration in Forst's sense requires that practices of toleration draw the limits of toleration in a manner that is suitably justifiable to relevant people - that is, the legal, political, or other constraints that spring from its view of these limits must be justifiable to all affected people on the basis of reasons that are equally acceptable by them. After reconstructing this conception, this chapter interrogated the idea of reasonableness that comes with the idea of reciprocal and general justification on which Forst premises non-domination toleration. And it 
addressed the idea of equal respect, or one key implication of it, that reciprocal and general justification builds on and that is at the heart of the republican understanding of non-domination that underpins Forst's view of non-domination toleration.

The chapter pointed toward two issues. First, even if non-domination toleration is possible only where people are suitably respected as equals and salient constraints are equally justifiable to them, the kind of justification called for here arguably should not be understood in terms of Forst-type reciprocal and general justifiability: for it is not clear what it means for (putatively) justifying reasons to be "reciprocally and generally" acceptable, or to be "reasonably" non-rejectable.

Second, given the purposes of non-domination toleration, equal (discursive) respect calls for a form of discursive equality that is not just formal, but purchase sensitive. If practices of toleration must only impose constraints that are justifiable by reasons that people can equally accept authoritatively, then non-domination outcomes are not ensured if the authoritativeness constrains that are in play do not allocate discursive influence permissibly, or justly.

But what allocation of this potentially highly important discursive good does nondomination toleration call for? On this, the jury is still out.

\section{References}

Allen A (2015) Feminist perspectives on power. In: Zalta EN (ed) Stanford encyclopedia of philosophy. The Metaphysics Research Lab, Center for the Study of Language and Information (CSLI), Stanford University, Stanford

Azmanova A (2018) Relational, structural and systemic forms of power: the 'right to justification' confronting three types of domination. J Polit Power 11(1):68-78

Besch TM (2010) Diversity and the limits of liberal toleration. In: Ivison D (ed) The Ashgate research companion to multiculturalism. Routledge, London, pp 75-94

Besch TM (2012) Political liberalism, the internal conception, and the problem of public dogma. Philoso Public Issues 2(1):153-177

Besch TM (2014) On discursive respect. Soc Theory Pract 40(2):207-231

Besch TM (2018) Public justification, inclusion, and discursive equality. Dialogue: Can Philos Rev/ Revue Canadienne de Philosophie 57(3):591-614

Besch TM (2019a) On robust discursive equality. Dialogue: Can Philos Rev/Revue Canadienne de Philosophie 58(3):465-490

Besch TM (2019b) On justification, idealization, and discursive purchase. Philosophia 47 (3):601-623

Besch TM (2020) Forst on reciprocity of reasons: a critique. South J Philos (in press)

Carter I, Ferretti M (2013) Introduction, special issue on toleration and respect. J Appl Philos 30 (3):191-194

Catala A (2015) Democracy, trust, and epistemic justice. Monist 98(4):424-440

Cohen J (2006) Is there a human right to democracy? In: Sypnowich C (ed) The egalitarian conscience: essays in honour of GA Cohen. Oxford University Press, Oxford, pp 226-248

Darwall SL (1977) Two kinds of respect. Ethics 88(1):36-49

Dieleman S (2015) Epistemic justice and democratic legitimacy. Hypatia 30(4):794-810

Fletcher G (1996) The instability of tolerance. In: Heyd D (ed) Toleration: an elusive virtue. Princeton University Press, Princeton, pp 158-172

Forst R (2001) Towards a critical theory of transnational justice. Metaphilosophy 32(1-2):160-179

Forst R (2003a) Toleranz im Konflikt. Suhrkamp, Frankfurt am Main 
Forst R (2003b) Toleration, justice and reason. In: McKinnon C, Castiglione D (eds) The culture of toleration in diverse societies. Manchester University Press, Manchester

Forst R (2010) The justification of human rights and the basic right to justification: a reflexive approach. Ethics 120(4):711-740

Forst R (2012) The right to justification: elements of a constructivist theory of justice. Columbia University Press, New York

Forst R (2013) A Kantian republican conception of justice as non-domination. In: Niederberger A, Schink P (eds) Republican democracy: liberty, law and politics. Edinburgh University Press, Edinburgh, pp 154-168

Forst R (2017a) Normativity and power: analyzing social orders of justification. Oxford University Press, Oxford

Forst R (2017b) Noumenal alienation: Rousseau, Kant and Marx on the dialectics of self-determination. Kantian Rev 22(4):523-551

Galeotti AE (2002) Toleration as recognition. Cambridge University Press, Cambridge

Honohan I (2013) Toleration and non-domination. In: Dobbernack J, Modood T (eds) Tolerance, intolerance and respect. Palgrave politics of identity and citizenship series. Palgrave Macmillan, London, pp 77-100

Jenkins D, Lukes S (2017) The power of occlusion. Journal of Political Power 10(1):6-24

King PT (1998) Toleration. Frank Cass Publishers, London

Kymlicka W (1996) Multicultural citizenship: a liberal theory of minority rights. Oxford University Press, Oxford

Larmore C (2015) Political liberalism: its motivation and goals. In: Sobel D, Vallentyne P, Wall S (eds) Oxford studies in political philosophy, vol 1. Oxford University Press, New York, pp $63-88$

Lovett F (2010) A general theory of domination and justice. Oxford University Press, Oxford

Macedo S (1991) Liberal virtues: citizenship, virtue, and community in liberal constitutionalism. Oxford University Press, Oxford

McKinnon C (2006) Toleration: a critical introduction. Routledge, New York

Mendus S (1988) Justifying toleration: conceptual and historical perspectives. Cambridge University Press, Cambridge

Moore M (1996) On reasonableness. J Appl Philos 13(2):167-178

Newey G (2013) Toleration in political conflict. Cambridge University Press, Cambridge

Peter F (2009) Democratic legitimacy. Routledge, New York

Pettit P (2012) On the people's terms: a republican theory and model of democracy. Cambridge University Press, Cambridge

Postema GJ (1995) Public practical reason: an archeology. Soc Philos Policy 12(1):43-86

Rawls J (2005) Political liberalism, Expanded edition. Columbia University Press, New York

Raz J (1986) The morality of freedom. Clarendon Press, Oxford

Rossi E (2013) Can tolerance be grounded in equal respect? Eur J Polit Theo 12(3):240-252

Scanlon TM (2003) The difficulty of tolerance: essays in political philosophy. Cambridge University Press, Cambridge

Steinhoff U (2015) Against equal respect and concern, equal rights, and egalitarian impartiality. In: Steinhoff U (ed) Do all persons have equal moral worth? On 'basic equality' and equal respect and concern. Oxford University Press, Oxford, pp 142-172

Wall S (2016) The pure theory of public justification. Soc Philos Policy 32(2):204-226

Williams B (1996) Toleration: an Impossible Virtue? In: Heyd D (ed) Toleration: an elusive virtue. Princeton University Press, Princeton, pp 18-27 